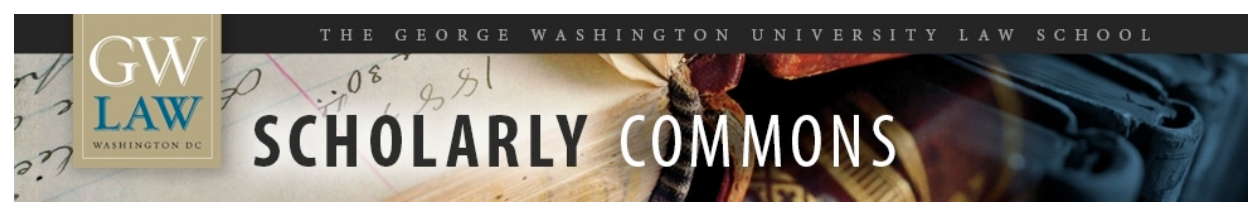

\title{
A Brief Illustrated Chronicle of Retroactive Copyright Term Extension
}

Robert Brauneis

The George Washington University Law School, rbraun@law.gwu.edu

Follow this and additional works at: https://scholarship.law.gwu.edu/faculty_publications

Part of the Law Commons

\section{Recommended Citation}

Brauneis, Robert, A Brief Illustrated Chronicle of Retroactive Copyright Term Extension (May 27, 2015). Available at SSRN: https://ssrn.com/abstract=2611311 or http://dx.doi.org/10.2139/ssrn.2611311

This Article is brought to you for free and open access by the Faculty Scholarship at Scholarly Commons. It has been accepted for inclusion in GW Law Faculty Publications \& Other Works by an authorized administrator of Scholarly Commons. For more information, please contact spagel@law.gwu.edu. 


\title{
A BRIEF ILLUSTRATED CHRONICLE OF RETROACTIVE COPYRIGHT TERM EXTENSION
}

\author{
Robert Brauneis ${ }^{*}$
}

At least since the Supreme Court's 2003 decision in Eldred v. Ashcroft, it has been widely known that whenever Congress has extended copyright term, it has done so retroactively, granting the benefit of the extension to all works still under copyright on the effective date of the extension. ${ }^{2}$ However, I have never found succinct, complete tables and charts detailing the periods during which works received various copyright terms given the retroactive effect of all extension legislation. ${ }^{3}$ It is the modest aim of this article to provide

\footnotetext{
* Professor of Law and Co-Director of the Intellectual Property Law Program, The George Washington University Law School. I would like to thank Laura Gasaway, Ellen Goodman, Peter Hirtle, Tyler Ochoa, Zvi Rosen, Roger Schechter, and Elizabeth Townsend-Gard for perceptive comments that greatly improved this article, and David Micklethwait for important details about Noah Webster and the Copyright Act of 1831. I would like to thank Hersh Acharya for research assistance. For financial support, I would like to thank Dean Blake Morant. I performed some of the research presented in this article while I was the Kamenstein Scholar in Residence at the U.S. Copyright Office. For support in that position, I would like to thank the Register of Copyrights, Maria A. Pallante.

${ }^{1} 537$ U.S. 186 (2003).

${ }^{2}$ See, e.g., id. at 200 ("History reveals an unbroken congressional practice of granting to authors of works with existing copyrights the benefit of term extensions so that all under copyright protection will be governed evenhandedly under the same regime"); id. at 237 (Stevens, J., dissenting) ("To be sure, Congress, at many times in its history, has retroactively extended the terms of existing copyrights and patents."); Tyler Ochoa, Patent and Copyright Term Extension and the Constitution: An Historical Perspective, 49 J. Copyright Soc'y 19, 26-46 (2001) (discussing retroactive extension of copyright term by means of general laws).

${ }^{3}$ Laura Gasaway and Peter Hirtle have provided useful charts detailing when works pass into the public domain. See Laura Gasaway, When U.S. Works Pass into the Public Domain, http://www.unc.edu/-unclng/public-d.htm (last visited May 3, 2015); Peter B. Hirtle, Copyright Term and the Public Domain in the United States, https://copyright.cornell.edu/resources/publicdomain.cfm (last visited May 3, 2015).
} 
that information, and to provide some examples of the operation of retroactive term extension.

Although this article does not advance any particular thesis on the subject of copyright terms, as an enticement to read further I will suggest that chronicling the reach of retroactive copyright term extension not only helps to figure out when particular works entered the public domain, but leads to some interesting general observations. For example, it may not have previously struck many that July l, 1867 is a significant date in copyright history, and yet it is, because it is the last date on which copyright term expectations coincided with copyright term reality. Those who acquired federal copyright protection for their works on July 1, 1867 expected to get a maximum of 42 years of protection, because that is the term that the Copyright Act provided for at the time. That is exactly what they got: copyright in all works in which protection was acquired on July 1,1867 did indeed expire by June 30, $1909-42$ years later. From July 2, 1867 to the present day, however, retroactive term extension has made every work that has acquired federal copyright protection eligible for a longer term than the term in force when it acquired that protection.

Correlatively, although it is frequently mentioned that the maximum term of copyright under the Copyright Act of 1909 was 56 years, not a single work that gained federal copyright protection while the 1909 Act was in force, from July l, 1909 through December 31, 1977, ended up receiving a copyright term of 56 years. All such works ended up being eligible to receive either 75 or 95 years of protection. The works that ended up receiving 56 years of protection gained federal copyright protection during an earlier period, between July 2, 1867 and September 19, 1906.

Part I of this Article addresses the prospective and retrospective maximum terms of copyright for works acquiring federal copyright protection from 1790 to 1977 . It presents one chart and one table summarizing that protection, and then presents the statutory

However, those charts focus on the present and the future, and therefore do not give a complete historical perspective. Tom Bell has created a chart that comes closest to providing that historical perspective. See Tom W. Bell, Trend of U.S. Maximum General Copyright Term, http://www.tomwbell.com/writings/(C) Term.html (last visited May 3, 2015). That chart, however, is not accompanied by exact dates, nor by an explanation of which events start the copyright term clock running, or which pieces of legislation combined to create all of the terms and the periods during which those terms were valid. 
interpretation underlying that chart and table while adding some details that cannot be accommodated in simple graphic form. Part II summarizes prospective and retrospective maximum copyright terms from 1978 to the present. Part III provides a few remarks on the difference between maximum and actual copyright term. Part IV concludes by looking to the future, and explaining why the next time we will know whether prospective and retrospective terms once again coincide - assuming there is no further retroactive legislation in the meantime - is midnight on December 31, 2068. 


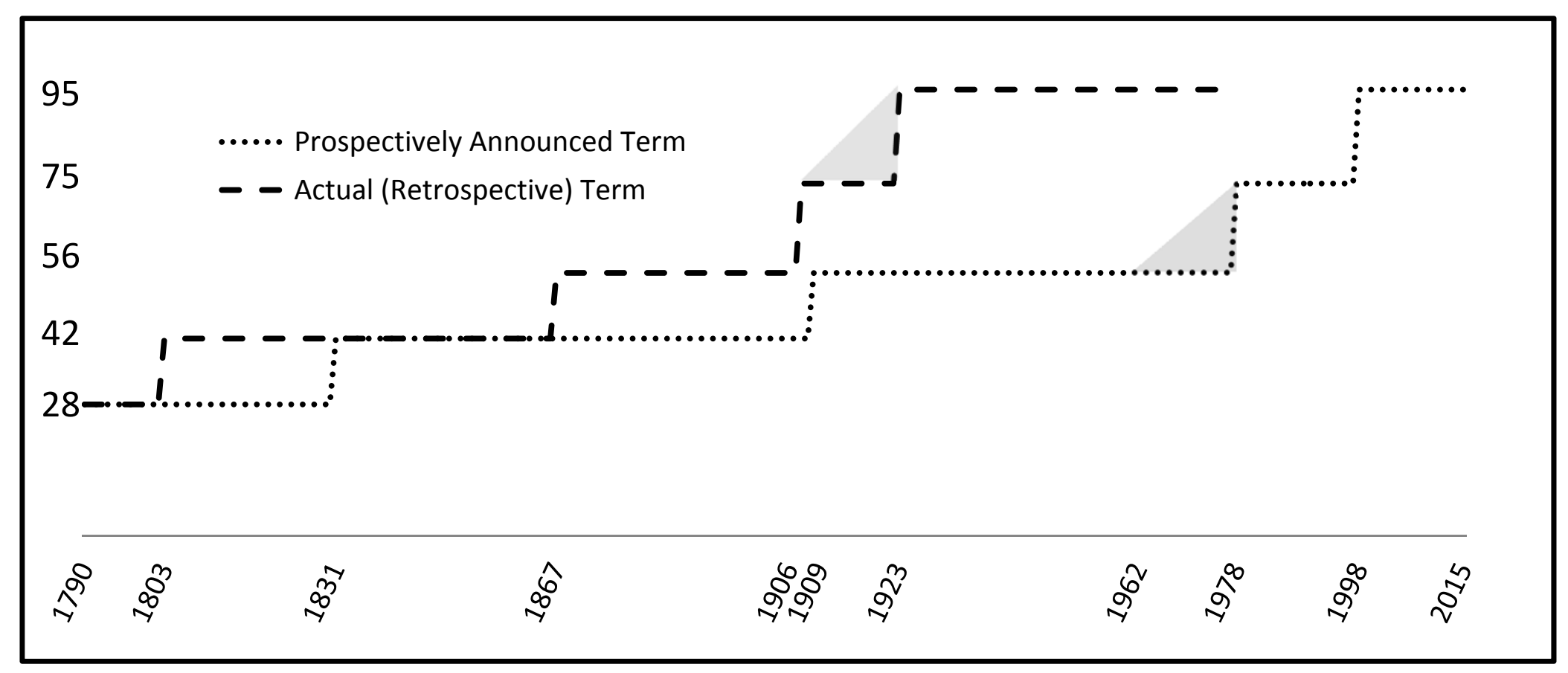

Figure 1: Maximum Term of Copyright, Prospectively Announced and Actual, For Works Acquiring Federal Copyright 1790-1977

from Robert Brauneis, A Brief Illustrated Chronicle of Retroactive Copyright Term Extension 


\section{Table 1: Periods During Which Various Terms of Copyright Were Available, \\ For Works Acquiring Federal Copyright 1790-1977}

\begin{tabular}{|c|c|c|c|c|}
\hline \multirow{2}{*}{$\begin{array}{l}\text { Period during which } \\
\text { term was } \\
\text { prospectively } \\
\text { announced } \\
\text { (dates during which } \\
\text { legislation } \\
\text { designating term was } \\
\text { in force) }\end{array}$} & \multirow{2}{*}{$\begin{array}{l}\text { Period during which } \\
\text { term was actually } \\
\text { (retrospectively) } \\
\text { applied } \\
\text { (dates of registration } \\
\text { or first publication of } \\
\text { works receiving term } \\
\text { given retroactive } \\
\text { effect of legislation) }\end{array}$} & \multirow{2}{*}{$\begin{array}{l}\text { Maximum Term } \\
\text { (in years) }\end{array}$} & \multicolumn{2}{|r|}{ Some Details } \\
\hline & & & $\begin{array}{l}\text { Initial Term } \\
\text { (in years) }\end{array}$ & $\begin{array}{l}\text { Renewal Term } \\
\text { (in years) }\end{array}$ \\
\hline $\begin{array}{l}\text { May 31, } 1790- \\
\text { February 2, } 1831\end{array}$ & $\begin{array}{l}\text { May 31, } 1790- \\
\text { February 3, } 1803\end{array}$ & 28 & 14 from date of registration & $\begin{array}{l}14 \text { if author still alive at end of first term; } \\
\text { fully assignable, devisable, descendible }\end{array}$ \\
\hline $\begin{array}{l}\text { February 3, } 1831- \\
\text { June 30, } 1909\end{array}$ & $\begin{array}{l}\text { February 4, } 1803- \\
\text { July } 1,1867\end{array}$ & 42 & 28 from date of registration & $\begin{array}{l}\text { 14; renewal right to surviving author, or if } \\
\text { author dead to surviving widow, child or } \\
\text { children; for registrations before February } 3 \text {, } \\
\text { 1831, surviving author may have no right of } \\
\text { renewal. }\end{array}$ \\
\hline $\begin{array}{l}\text { July } 1,1909 \text { - } \\
\text { September } 18,1962\end{array}$ & $\begin{array}{l}\text { July 2, } 1867- \\
\text { September 19, } 1906\end{array}$ & 56 & $\begin{array}{l}28 \text { (from date of registration } \\
\text { as retrospectively applied) }\end{array}$ & 28 \\
\hline $\begin{array}{l}\text { September } 19,1962- \\
\text { October } 26,1998 \\
\text { (after } 10 \text { incremental } \\
\text { increases in term) }\end{array}$ & $\begin{array}{l}\text { September 20, } 1906 \text { - } \\
\text { December 31, } 1922\end{array}$ & 75 & $\begin{array}{l}28 \text { (from date of registration } \\
\text { until July } 1,1909, \text { then from } \\
\text { date of publication with } \\
\text { notice; for qualifying } \\
\text { unpublished works, from } \\
\text { date of deposit) }\end{array}$ & $\begin{array}{l}47 \text { (plus until the end of the calendar year in } \\
\text { which the renewal term ended) after } 10 \\
\text { Acts beginning September 19, } 1962 \text { and } \\
\text { ending October 19, } 1976\end{array}$ \\
\hline $\begin{array}{l}\text { October 27, } 1998 \text { - } \\
\text { present }\end{array}$ & $\begin{array}{l}\text { January 1, 1923- } \\
\text { December 31, } 1977\end{array}$ & 95 & $\begin{array}{l}28 \text { (from date of publication } \\
\text { with notice; for qualifying } \\
\text { unpublished works, from } \\
\text { date of deposit or } \\
\text { registration) }\end{array}$ & $\begin{array}{l}67 \text { (plus until the end of the calendar year in } \\
\text { which the renewal term ended) (automatic } \\
\text { renewal effective for works gaining } \\
\text { protection on or after Jan 1, 1964) }\end{array}$ \\
\hline
\end{tabular}




\section{Prospective and Retrospective Copyright Term for Works Acquiring Federal Copyright Protection from May 31, 1790 through} December 31, 1977

Figure 1 and Table 1 show the periods during which various terms of federal copyright protection were available for works that acquired federal copyright protection from May 31, 1790 through December 31, 1977. ${ }^{4}$ Figure 1 provides a rough overview of copyright terms that does not include exact dates, but only years. The dotted line shows the increases in term as they were prospectively announced, while the dashed line shows terms as they were retroactively applied. When the two lines converge, works ended up being eligible to receive the maximum term of copyright that was announced as being in force at the time copyright was acquired. When they diverge, works ended up being eligible to receive a longer term of copyright than that announced at the time of acquisition of copyright. The two periods during which expected copyright term equaled actual copyright term were 1790 to 1803 and 1831 to 1867 . Thus, for two periods totaling about 48 years and ending in 1867, expected and actual copyright term coincided. For the two remaining periods that together span about 138 years - 1803-1831 and 1867-1977 - actual copyright term ended up being longer than expected term. The shaded triangular areas acknowledge that Congress began to retroactively extend copyright term for works still under copyright in 1962, and incrementally extended that term nine times before reaching the 75-year maximum announced in the Copyright Act of 1976. I will provide details about those incremental extensions below.

Table 1 starts to provide more detail. It fills in the exact dates during which particular maximum copyright terms were prospectively and retrospectively available. A general comment about these exact dates is in order. Before the first incremental extension of copyright

\footnotetext{
${ }^{4}$ As most readers will know, until January 1, 1978, unpublished works were protected under common law copyright, which at least now is thought to be exclusively a matter of state and not federal law. While some unpublished works could also be protected under federal law through registration, works first published after the effective date of the Copyright Act of 1790 - May 31, 1790 - could be protected only under federal law. See Wheaton v. Peters, 33 U.S. (8 Pet.) 591 (1834). Works that acquired federal copyright protection on or after January l, 1978 will be treated separately below. The term of protection for a work in that latter category, when authored by an identified natural person, is measured by the life of the author plus a number of years, rather than a fixed number of years after acquisition of copyright, rendering unified graphic display of pre-1978 and post-1978 terms difficult.
} 
term in 1962, the term of copyright was calculated to the exact day. Thus, for example, the reporter's note in the 1862 case of Cowen v. Banks explains that copyright in one of the works at issue in that case - a volume of cases decided in New York state courts, as reported by Judge Esek Cowen - was alleged to have expired on November 13, $1843^{5}$ Copyright registration records of the Southern District of New York include a record dated November 13, 1829 - exactly fourteen years earlier to the day - for volume IX of Cowen's reports. ${ }^{6}$ That practice continued under the Copyright Act of 1909 even though the general measuring date changed from the date of registration to the date of first publication - a date that was not necessarily contemporaneously recorded, and hence was in some cases difficult or impossible to ascertain. Hence, the 1973 Compendium of Copyright Office Practices stated: "Copyright begins on the date of first publication, as shown by the original application and other office records, and lasts for twentyeight years from that exact date."

When the Copyright Office began to consider revision of copyright law in the late 1950s and early 1960s, it recognized that determining exact dates of events other than registration was difficult, and therefore recommended having copyright expire at the end of the calendar year. Thus, the 1961 Report of the Register of Copyrights states:

The copyright term now expires 28 or 56 years from the precise day of first publication or earlier registration.

We propose that in all cases the term should run until the end of the calendar year in which it would otherwise expire. This provision, found in most foreign laws, would simplify the computation of the term. It would then be enough to determine

\footnotetext{
${ }^{5}$ See Cowen v. Banks, 6 F. Cas. 669, 669 (C.C.N.Y. 1862).

${ }^{6}$ See Copyright Record Books of the District Courts 1790-1870 (hereinafter "District Court Copyright Record Books"), vol. 137 (Southern District New York December 1828 - February 1831) (Microfilm Reel 30), no. 175; image available at http://docs.law.gwu.edu/facweb/rbrauneis/retroactive/CowenReg.pdf. The Library of Congress catalog record for the Copyright Record Books series is available at http://lccn.loc.gov/84114199; I have posted the 37-page catalog of those records at http://docs.law.gwu.edu/facweb/rbrauneis/retroactive/Catalog of District_Court_Co pyright Record Books 1790 1870.pdf

${ }^{7}$ See Compendium of Copyright Office Practices (hereinafter "Compendium One") $\mathbb{}$ 11.1.1 (July $1, \quad 1973$ ) (emphasis added), available at http://copyright.gov/history/comp/compendium-one.pdf (last visited May 22, 2015).
} 
the year, rather than the exact date, of the event from which the term is computed. ${ }^{8}$

The first incremental extension of copyright, passed on September 19, 1962 and applicable to all works still under copyright on that day, incorporated that proposal, and extended copyright in those works to December 31, 1965..$^{9}$ Subsequent incremental extensions also incorporated year-end expiration of copyright, as did the Copyright Act of $1976 .{ }^{10}$ Thus, September 19, 1962 is the date of transition from exactday to year-end expiration of copyright.

Table 1 assumes that a year of copyright protection would not include both the date that the protection began and that same date one year later, but would rather terminate at the end of the day before the date of the first anniversary of the beginning of protection. In other words, copyright hypothetically acquired for a term of one year on January lst of a given year would run through December $31^{\text {st }}$ of that year, and would end at midnight - the moment that December $31^{\text {st }}$ ended and January $\mathrm{l}^{\text {st }}$ of the next year began. If the term of copyright ran through January $1^{\text {st }}$ of the next year, the grant would actually be for a year and a day. ${ }^{11}$

${ }^{8}$ Copyright Law Revision: Report of the Register of Copyrights on the General Revision of the U.S. Copyright Law, House Committee Print, $87^{\text {th }}$ Cong., $1^{\text {st }}$ Sess., at 56 (July 1961); cf.James J. Guinan, Jr., Duration of Copyright, Study No. 30, at 74 (January 1957), in Copyright Law Revision: Studies Prepared for the Subcommittee on Patents, Trademarks, and Copyrights of the Committee on the Judiciary, United States Senate, Eighty-Sixth Congress, Second Session Pursuant to S. Res. 240, Studies 29-31 (Committee Print 1961) ("In those countries which have adopted [a term based on the life of the author], the term is generally measured from the last day of the calendar year in which the author died, or the first day of the succeeding year, thus making it necessary to know only the year in which he died rather than the exact date. It might be worth considering this latter provision in connection with this or any of the other possible starting points for the term.").

${ }_{9}^{9}$ Pub. L. 87-668, 76. Stat. 555 (September 19, 1962).

${ }^{10}$ See infra n. 57 (listing the incremental extensions); 17 U.S.C. $\$ \$$ 304(a), 304(b), 305 (1976) (providing for year-end expiration of copyright both retroactively and prospectively); H.R. Rep. No. 94-1574, at 142 (1976), reprinted in 1976 U.S.C.C.A.N. 5659 (explaining the rationale of year-end termination) ("This will make the duration of copyright much easier to compute, since it will be enough to determine the year, rather than the exact date, of the event from which the term is based.").

${ }^{11}$ In determining the period during which it was possible to file a renewal registration, the Copyright Office followed a more generous rule. According to the first Compendium of Copyright Office Practices, "The renewal year . . comprises both the twenty-seventh and twenty-eighth anniversaries of the date on which copyright began," Compendium One, supra n. 7 , at $\$ 11.2 .2$, which of course adds up to a year and 
The "Some Details" column of Table 1 also notes that the maximum term has until recently not been a unified term, but has been composed of an initial or original term and a renewal term. The latter has been subject to various conditions and available to various parties over time. To explain and substantiate each of the entries in Table l, and to add some additional details, I will address in turn each of the pieces of legislation that creates one or more entries in the table.

A. The Copyright Act of 1790. The Copyright Act of 1790 was signed into law on May 31, 1790. ${ }^{12}$ To gain copyright protection under that Act, the author of a "map, chart, [or] book" or his assignee had to "deposit a printed copy of the title [thereof] in the clerk's office... of the district court where the author or proprietor shall reside." ${ }^{13}$ The clerk then recorded that title, noting the date of recording, and an

a day. In addition, "[i]f the original copyright expires on a Saturday, Sunday, or holiday within the District of Columbia, renewal action may be taken on the next succeeding business day." Id. $\$$ 12.2.2.IV. Presumably, neither of those sections extended the original term of copyright even if no renewal was made; rather, they rendered retroactively effective a renewal that was made a day or two after the end of the original term.

${ }^{12}$ See An Act for the encouragement of learning, by securing the copies of maps, charts, and books, to the authors and proprietors of such copies, during the times therein mentioned (May 31, 1790), in Public Statutes at Large of the United States of America, from the organization of the Government in 1789, to March 3, 1845, p. 124 (Richard Peters, ed., 1845) (hereinafter "Copyright Act of 1790").

${ }^{13}$ Id. $\$ 3$. To maintain copyright protection, the owner of copyright also had to make sure that a copy of the record made by the clerk was published in one or more newspapers within two months, see id., and to deliver a copy of the map, chart, or book to the Secretary of State within six months, see id. $\$ 4$. An amendment in 1802 added the further requirement of placing copyright notice in a required form in each copy of any book for which federal copyright protection was secured. See An Act supplementary to an act, intituled, "An act for the encouragement of learning, by securing the copies of maps, charts, and books, to the authors and proprietors of such copies, during the times therein mentioned," and extending the benefits thereof to the arts of designing, engraving and etching historical and other prints (April 29, 1802), in Public Statutes at Large of the United States of America, from the organization of the Government in 1789, to March 3, 1845, p. 171 (Richard Peters, ed., 1845). However, it was the deposit and recording of the title of the map, chart or book that triggered the term of copyright protection. See, e.g., James J. Guinan, Jr., Duration of Copyright, supra n. 8, at 58 ("[R] ecording of the title of the work in the office of the clerk of the District Court prior to publication was required to secure copyright, and the term was measured from the date of recording the title, rather than from the date of publication as in the Statute of Anne and earlier State legislation."). 
initial term of fourteen years of protection began on that date. ${ }^{14}$ As noted above, the term was exactly fourteen years from the date of recordation - fourteen years to the day.

One example of how copyright term was calculated under the 1790 Act involves the very first book to gain federal copyright protection in the United States. On June 9, 1790, the Clerk of the District Court of Pennsylvania recorded John Barry's deposit of the title of his book "The Philadelphia Spelling Book." 15 The last day of the first term of copyright for that book was therefore June 8, 1804, exactly 14 years later. The Copyright Act of 1790 also provided for a renewal term of an additional fourteen years, on two conditions. First, at the end of the first term the author had to still be alive and be a citizen or resident of the United States. Second, within the last six months of the first term the title of the work had to again be deposited with the clerk of court. $^{16}$ The Act granted the renewal term to the author "or his . . . executors, administrators or assigns," thus making the renewal right fully assignable, devisable, and descendible. ${ }^{17}$ On January 23, 1804, the

${ }^{14}$ Id. $\$ 1$. As Copyright Office regulations later made explicit, "The title is recorded on the day of its receipt in the Copyright Office, in accordance with the provisions of the copyright statutes, and no date prior to the day of receipt can be given to the entry of title." Directions for Registering Copyrights p. 14 (May 1900), in A Compilation of the Regulations Concerning Copyright 1874-1956, p. 107 (emphasis in original). Although the Copyright Act of 1790 speaks of "depositing" the title of a book, and of the clerk "recording" that title, those are both steps in what we would now call "registration"; modern copyright terminology reserves "deposit" for the process of submitting a copy or copies of a work, and "recording" for the process of placing on public record documents pertaining to copyright. However, the modern registration process involves examination of the deposit copy to determine whether it contains copyrightable subject matter; "registration" in the early $19^{\text {th }}$ century had no examination component.

${ }^{15}$ See Federal Copyright Records, 1790-1800 (James Gilreath, ed., Elizabeth Carter Wills, comp.), p. 1 (1987) (presenting an entry from the Pennsylvania District Court Ledger, 262 PA 1, which notes that on June 9, 1790, the title of "The Philadelphia Spelling Book" was deposited, listing John Barry as both the claimant and author).

${ }^{16}$ See Copyright Act of $1790 \$ 1$.

${ }^{17}$ See id. Of course, the "executors" of the author could not file a renewal registration, since an author would only have executors if he had died, and the 1790 Act granted a renewal term only if the author lived through the end of the initial term. However, if the author successfully renewed but died during the renewal term, his ownership interest in the renewal term would pass through his executors to his devisees or heirs. As for assignees, if the author had explicitly assigned rights in the renewal term in advance and survived the initial term, presumably the assignee of those rights could file a renewal registration, as Henry Sweitzer did for "The Philadelphia Spelling Book." 
Clerk of the District Court of Pennsylvania recorded Henry Sweitzer's deposit of the title of John Barry's book "The Philadelphia Spelling Book," with Sweitzer's claim to be proprietor of copyright in that book. $^{18}$ Assuming that Sweitzer was the assignee of John Barry, and that Barry was still alive on June 9, 1804, the book then enjoyed protection through June 8,1818 , and entered the public domain on June $9,1818 .^{19}$

Because the Copyright Act of 1790 was the first federal copyright act, it could not retroactively increase the term of copyright for any works that were previously under federal copyright protection, because there were no such works. As for works not yet published at the time the 1790 Act was passed, the Act required that their titles be deposited with the relevant clerks of court before publication in order to gain protection. ${ }^{20}$ However, the Act did allow works already published at the time the Act was passed to gain the two fourteen-year terms of federal copyright protection described above. ${ }^{21}$ One prominent

${ }^{18}$ See District Court Copyright Record Books, supra n. 6, vol. 262 (Pennsylvania June 9, 1790 - December 24, 1804) (Microfilm Reel 61), no. 27. The record of Henry Sweitzer's deposit does not note that it is a second-term or renewal deposit, and thus provides the public with incomplete information. Looking at that record alone, one would not know that the copyright in the work could not be further renewed, nor would one know the date that the second term ended (which would be, not exactly fourteen years from the date of recording the second-term title deposit, but exactly fourteen years after the date that the first term ended).

I should also note that most early record books do not record the year according to the Gregorian calendar, but according to the "Year of Independence." The first Year of Independence began on July 4, 1776 and ended on July 3, 1777, and every succeeding Year of Independence runs from July 4 through July 3. Thus, the record of Henry Sweitzer's deposit is recorded as having been made on the "twenty third day of January in the twenty eighth year of the Independence of the United States of America." In Gregorian terms, the $28^{\text {th }}$ Year of Independence began on July 4 , 1803 and ended on July 3, 1804. Any date from July 4 through December 31 in that Year of Independence would fall in 1803; any date from January 1 through July 3 in that Year of Independence would fall in 1804.

${ }^{19}$ There is an ongoing controversy whether the author of the Philadelphia Spelling Book was the same John Barry as the Revolutionary War naval officer who is often referred to as the "Father of the American Navy." See William Kelly, "John Barry and John Barry," http://remembertheintrepid.blogspot.com/2008/04/john-barry-and-johnbarry.html (last visited May 9, 2015). The latter died on September 13, 1803. See John Barry (naval officer), http://en.wikipedia.org/wiki/John Barry_(naval officer). If there was only one John Barry, then his death before the end of the first term of copyright would have precluded a second term.

${ }^{20}$ Seeid.

${ }^{21}$ See Copyright Act of $1790 \$ 1$. 
example of a work that gained such protection was Noah Webster's A Grammatical Institute of the English Language. In the 1780s, Webster had obtained copyright protection for his Grammatical Institute in several states. $^{22}$ On October 7, 1790, Webster's publishers, Isaiah Thomas and Ebenezer T. Andrews, obtained federal copyright protection for that book. ${ }^{23}$ As William Maher has shown, however, acquisition of federal copyright in the early years of the 1790 Act was rare, and acquisition of copyright for books already published even rarer. Of the approximately 21,000 printed editions of books, charts and maps in the United States between 1790 and 1800, there are copyright registration records for only 684; of those 684 registrations, only 12 registrations were for previously published works. ${ }^{24}$ Thus, the registrations for previously published works amount to less than $2 \%$ of copyright registrations, and less than $0.06 \%$, or about one in 2000 , of printed editions. ${ }^{25}$

B. The Copyright Act of 1831. On February 3, 1831, Congress passed a comprehensive revision of federal copyright law. ${ }^{26}$ That Act retained many features of federal copyright duration under the 1790 Act, including the divided structure of an initial term and a renewal term, the provision that the initial term would begin on the date that the title of the work was recorded, and the renewal term's length of 14 years. ${ }^{27}$ At the same time, the 1831 Act increased the initial term of copyright to 28 years, and it dropped the requirement that the author survive until the beginning of the renewal term to obtain such a term. Section 2 of the Act, applicable to works first gaining federal copyright protection on or after its effective date, specified that the new renewal term vested in the author, or if the author had died, in the author's widow, child, or children. ${ }^{28}$

\footnotetext{
${ }^{22}$ See Federal Copyright Records, 1790-1800, supra n. 15, at xx-xxi; William J. Maher, Copyright Term, Retrospective Extension, and the Copyright Law of 1790 in Historical Context, 49 J. Copyright Soc'y U.S.A. 1021, 1033-34 (2002).

${ }^{23}$ See Federal Copyright Records, 1790-1800, supra n. 15, at 74 (presenting an entry from the Massachusetts District Court Ledger, 42 MA 2, which notes that on October 7, fifteenth year of Independence, Isaiah Thomas \& Eben. T. Andrews deposited the title of a book written by Noah Webster Junior Esquire.

${ }^{24}$ See Maher, supra n. 22, at 1023-25.

${ }^{25}$ See id.

${ }^{26}$ See An Act to amend the several acts respecting copyrights (Feb. 3, 1831), $21^{\text {st }}$ Cong., 2d Sess., ch. 16, 4 Stat. 439 (hereinafter "Copyright Act of 183l").

${ }^{27}$ See id. $\$ \$ 1,2$.

${ }^{28}$ See id. $\$ 1$.
} 
Although Section 16 of the 1831 Act raises at least two interpretive issues, to which I will return in a moment, it was clearly intended to extend the benefit of most of the Act's provisions, including the increased initial term, to some works that had already gained federal copyright protection. The retroactivity of that term extension was hardly an afterthought. The most vocal advocate for the extension was lexicographer Noah Webster, brother of Senator Daniel Webster and father-in-law of Representative William Ellsworth, the latter of whom were principal proponents of the 1831 Act in their respective Houses of Congress. ${ }^{29}$ Webster wanted extended copyright protection for his books, including books for which he had already received federal copyright protection.

The registration history for Webster's “An American Dictionary of the English Language," perhaps his most famous and enduring work, provides a good example of the uncontroversial working of retroactive extension under the 1831 Act. Webster had obtained federal copyright protection for that book by depositing its title on April 14, $1828 .{ }^{30}$ Under the 1790 Act as in effect at that time, Webster would have expected a 14-year initial term of copyright that would end on April 13, 1842. If he survived until that date (which he did, barely - he was 83, and died the following year at age 84$),{ }^{31}$ he or his assigns could have obtained a second 14-year term that would end on April 13, 1856. After the passage of the 1831 Act, the initial term for "An American Dictionary" was retroactively lengthened to 28 years, so that it ended on April 13, 1856. Webster was no longer alive on that date, but five of his children were, including Emily Ellsworth, wife of the 1831 Act's proponent Representative William Ellsworth. On January 9, 1856, those five children again deposited the title of "An American Dictionary of the English Language . . . in renewal of a copy-right for fourteen years, from the Expiration of the first copyright of the same book heretofore issued from this office, on the fourteenth day of April 1828 ...

\footnotetext{
${ }^{29}$ See Micklethwait, supra note 43, at 21l-221 (2000) (detailing Webster's campaign to lengthen the term of copyright). Noah Webster had also been active in lobbying for passage of copyright acts by the states in the 1780s, and for passage of the first federal copyright act in 1790, although Micklethwait argues that Webster was far less responsible for the passage of those acts than he claimed to be. See id. at 74-80.

${ }^{30}$ See District Court Copyright Record Books, supra n. 6, vol. 6 (Connecticut March 1825 - December 1841) (Microfilm Reel 1), p. 91, no. 552, image available at http://docs.law.gwu.edu/facweb/rbrauneis/retroactive/Websterrenewal.pdf.

${ }^{31}$ See II Connecticut Biographical Dictionary 564 (Caryn Hanna, ed. 2008) (Webster was born on October 16, 1758); id. at 565 (Webster died on May 28, 1843).
} 
$.32 \quad$ The retroactively extended term of copyright thus ended up expiring on April 13, 1870.

That brings us to the two interpretive issues raised by Section 16 of the 1831 Act. The first of those is, did the 1831 Act bestow an increased initial term of 28 years on works that were either in their initial terms or in their renewal terms on the date of passage of the Act, or only on works that were in their initial terms on that date? If the former, then the term extension would cover any work in which federal copyright protection was obtained on or after February 4, 1803; if the latter, the term extension would cover only those works in which federal copyright protection was obtained on or after February 4, 1817. Section 16 states that the extended term will apply "whenever a copyright has been heretofore obtained ... Provided, That this act shall not extend to any copyright heretofore secured, the term of which has already expired." ${ }^{33}$ On its face, that language would not seem to distinguish between initial and renewal terms, and I will argue that that is the better reading the Act. Professor Tom Bell's copyright term chart, however, appears to conclude that Section 16 makes the Act retroactively apply only to copyrights in their initial term on the Act's date of passage, and thus only to copyrights obtained on or after February $4,1817 .^{34}$ There would be a great deal of sense in that interpretation if the renewal term under the 1790 Act was not completely alienable. Under the Supreme Court's interpretation of the 1909 Act, for example, an author cannot make any advance assignment of the renewal term that would be enforced if that author dies before the end of the initial term. ${ }^{35}$ If the author does not survive until the end of the initial term, the 1909 Act preemptively intervenes to vest renewal rights in a defined class of beneficiaries. Retroactively extending the initial term of copyright in a case in which the renewal term was owned by a different party than the initial term would result in an immediate change in ownership, and it seems unlikely that Congress would have intended such a consequence.

32 See District Court Copyright Record Books, supra note 6, vol. 7 (Connecticut January 1842 - June 1859) (Microfilm Reel 1), p. 265, no. 1695, image available at http://docs.law.gwu.edu/facweb/rbrauneis/retroactive/AmericanDictionaryl856renew al.pdf.

${ }_{33}$ Copyright Act of 1831, supra n. 26, $\$ 16$.

${ }^{34}$ See Bell, supra n. 3.

${ }^{35}$ See Miller Music Corp. v. Charles N. Daniels, Inc., 362 U.S. 373 (1963). 
However, the entire structure of the 1831 Act's provisions respecting term is probably best viewed as reconciling the retroactive extension of that term, and the narrowing of the class of beneficiaries of the new renewal term, with the preservation of pre-existing expectations. The 28-year initial term of the 1831 Act essentially consolidated the previous Act's two 14-year terms, and then added a third 14-year term for the benefit of widows and children. Section 16 of the Act provided that the retroactively extended 28-year term would vest in the author, or if he had died before the date of the Act's passage, in the author's "executors, administrators, or assigns." ${ }^{36}$ That provision thus preserved whatever deals the author might have made before 1831 for either of the then-existing two 14-year terms of copyright. For example, any publisher to whom the author had assigned both of those 14-year terms would under the retroactive provisions of the 1831 Act own copyright for the duration of the 28-year initial term. Since twenty-eight is exactly two times fourteen, the publisher could not complain that the 1831 Act had disturbed any expectations. The only parties who could complain about expectations upset by the addition of another 14 years of copyright were members of the public. Although at least one Member of Congress did voice such complaints, ${ }^{37}$ they did not result in any legal challenge to the retroactive extension.

The number of renewal registrations under the 1831 Act for works that originally gained copyright before 1817 is undoubtedly very small. I have only been able to find one, though admittedly I have not done an exhaustive search; given the state of pre-1870 copyright records, an exhaustive search would take months or years. The one that I have found again concerns Noah Webster. Webster's second most famous work is probably "The American Spelling Book." Webster obtained federal copyright protection for that book (a revised version of the first part of the Grammatical Institutes, mentioned above ${ }^{38}$ ) by depositing its title in U.S. District Court for Connecticut on March 14, 1804. ${ }^{39}$ Before the initial term of copyright in that book expired,

${ }^{36} \mathrm{Id}$.

${ }^{37}$ See VII Gales \& Seaton's Register of Debates in Congress 423 (Jan. 6, 1831) (remarks of Mr. Hoffman) ("Mr. Hoffman opposed the bill, which appeared to be at variance with every principle of sound public policy. It went to establish a monopoly of which authors alone would reap the advantage, to the public detriment.")

${ }^{38}$ See supra p. 10.

39 The copyright registration records for March 1804 in Connecticut have not survived, but this is the date of registration found in the copyright notice on the American Spelling Book. See Noah Webster, The American Spelling Book (Thirtieth 
Webster deposited the title of that book a second time, on September 15, 1817.40 Under the 1790 Act, the second term would have expired on March 13, 1832. In the meantime, however, the Copyright Act of 1831 had been passed. Looking to take advantage of that Act's retroactive extension of the first term and new renewal term, Webster deposited the title of The American Spelling Book a third time, on September 26, $1831,{ }^{41}$ intending to gain another 14 years of protection.

Whether he in fact gained another 14 years of protection leads us to the second interpretive question raised by Section 16 of the 1831 Act. Section 2 of the 1831 Act, applicable to federal copyrights obtained on or after the date of the Act's passage, grants renewal rights to "the author ... or, if [he is] dead, to [his] widow and child, or children." By contrast, Section 16 of the Act, applicable to federal copyrights secured before the Act's date of passage, grants "the same right, to [the author's] widow, child or children to renew the copyright, at the expiration thereof, as is above provided in relation to copyrights originally secured under this Act." Thus, the Section 16 formulation does not explicitly grant the renewal right to the author, but only to his widow and children. Noah Webster apparently became convinced that because of that formulation, and because he was still alive at the end of the extended initial term of copyright in the American Spelling Book, his attempt to renew was ineffective, and the book entered the public domain. On a copy of a copyright bill that predated the 1831 Act, Webster wrote:

Revised Impression 1809), image of copyright notice page available at http://digital.library.pitt.edu/cgi-bin/t/text/pagevieweridx?c=nietz;cc=nietz;idno=00acf7166m;rgn=full\%20text;didno=00acf7166m;view=image; seq=8;node=00acf $7166 \mathrm{~m} \% 3 \mathrm{Al}$;page=root;size=s;frm=frameset; .

${ }^{40}$ See District Court Copyright Record Books, supra note 6, vol. 46 (Massachusetts April 1814 - 1825) (Microfilm Reel 8), no. 169.

${ }^{41}$ See District Court Copyright Record Books, supra note 6, vol. 6 (Connecticut March 1825 - December 1841) (Microfilm Reel 1) p. 235, no. 725. I originally thought that the 1831 Act's retroactive term extension might apply only to those works that were in their initial term of copyright on February 3, 1831, and not to those that were in their second or renewal term. Webster's third recording of a title originally recording in 1804, however, is good evidence that the 1831 Act should be read exactly as written to apply to any work still under copyright, regardless of the term. Part of my reason for thinking that the extension would not apply to works in their renewal term was that the renewal term might be owned by a different party than the initial term was, and retroactive extension of the initial term might therefore transfer ownership. However, under the 1790 Act, there were no restrictions on advance assignment or devise of the renewal term, and the 1831 Act preserved whatever assignments might have been made, so it would not have resulted in any transfers of ownership. 
The last section does not give the privilege of renewal to the widows \& children of deceased authors. This defect was supplied by Mr. Ellsworth, at my request, which had special reference to the case of the widow \& heirs of Dr. Dwight. But in redrafting the $16^{\text {th }}$ section Mr. Ellsworth omitted the words to him before the words the widow by which I lost the right of renewal of the American Spelling Book. N. Webster. ${ }^{42}$

I don't know how Webster came to this conclusion - I have not found any record of any litigation involving the renewal period of The American Spelling Book - but he apparently did, and it is consistent with the language of Section 16 of the Act. Thus, it is likely that, due to what was probably a drafting oversight, ${ }^{43}$ Section 16 granted rights in the new renewal term only to the author's "widow, child or children," so that authors of works that gained federal copyright protection before March 3, 1831 who survived to the end of the initial 28-year term could not obtain another 14-year term, and their works fell into the public domain at the end of that initial term.

C. The Copyright Act of 1909. Although the Copyright Act of 1870 introduced many important changes to copyright law, including centralization of copyright registration in the Library of Congress, ${ }^{44}$ it retained the copyright term provisions of the 1831 Act. ${ }^{45}$ The next changes made to copyright term were in the Copyright Act of 1909, which became law on March 4, 1909 and provided for an effective date

\footnotetext{
${ }^{42}$ Noah Webster Papers, New York Public Library, Box 8, folder of papers related to N.W.'s struggle for copyright laws, copy of Amendment to H.R. 140, February 2l, 1828 , image available at http://docs.law.gwu.edu/facweb/rbrauneis/retroactive/HRl40Amendment.pdf. $\quad$ (see page 8 bottom). Many thanks to David Micklethwait for referring me to this handwritten note. The "Dr. Dwight" to whom Noah Webster refers is undoubtedly Timothy Dwight IV (1752-1817), a Congregationalist minister, the eighth President of Yale College, and a prolific author. Two of his most popular works were published posthumously: "Theology explained and defended in a Series of Sermons," published in 1818, and "Travels in New-England and New-York," published in 1821-1822. See Wikipedia, "Timothy Dwight IV," https://en.wikipedia.org/wiki/Timothy Dwight IV (last visited June 13, 2015).

${ }^{43}$ See David Micklethwait, Noah Webster and the American Dictionary 219 (2000) (explaining how Section 16 was hastily substituted for a previous version that would have required the author to live to the end of the first term, and opining that such haste probably resulted in a drafting mistake).

${ }^{44}$ See Act of July 8, 1870, SS 85, 90, 16 Stat. 198.

${ }^{45}$ See id. $\$ \$ 87,88$.
} 
of July 1, 1909. ${ }^{46}$ The 1909 Act retained a divided-term structure of an initial term and a renewal term. ${ }^{47}$ It also retained an initial term of 28 years, ${ }^{48}$ but it changed the basis on which federal copyright was acquired, and therefore changed the event that would start the 28-year term running. Under the 1909 Act, the initial term of federal copyright was generally acquired, not by the recording of the title of a work, but simply by publication of the work with proper copyright notice. ${ }^{49}$ Thus, the initial term ran for 28 years from the date of publication with notice $^{50}$ The Act, however, did allow some works to gain federal copyright protection without publication, "by the deposit, with claim of copyright, of one complete copy of such work ....".51 If a copy of an eligible work was properly deposited, then the initial 28-year term of copyright began running on the date of that deposit. ${ }^{52}$ The 1909 Act's term extension focused on the renewal term: that term was increased from 14 to 28 years. ${ }^{53}$

Section 24 of 1909 Act provided that its increased 28-year renewal term would apply to all works in which copyright still subsisted as of its effective date of July 1, 1909. ${ }^{54}$ Any work in which federal copyright had been secured on July 2, 1867 or later, and in which copyright had been validly renewed, would still be under copyright on July 1, 1909, 42 years later. Conversely, the term of a work in which

${ }^{46}$ See Act of Mar. 4, 1909, ch. 320, \$ 64, 35 Stat. 1080 (hereinafter "Copyright Act of 1909") (providing for an effective date of July l, 1909).

${ }^{47}$ See id. $\$ 23$. For one account of the background of the 1909 Act, see Ochoa, supra n. 2, at 33-39.

${ }^{48}$ Seeid.

${ }^{49}$ See id. $\$ 9$.

${ }^{50}$ See id. $\$ 23$.

${ }^{51}$ See id. $\$ 11$.

${ }^{52}$ The 1909 Act was actually silent on this issue, but the Ninth Circuit filled the gap in Marx v. United States, 96 F. 2d 204, 206-07 (9th Cir. 1938). See also Shilkret v. Musicraft Records, Inc., 131 F.2d 929, 932 (2d Cir. 1942) (citing Marx approvingly). The Copyright Office once used the date of deposit as the measuring date to begin the period of federal copyright protection for unpublished works, but then switched in 1949 to using the date of registration, meaning the date that deposit, application and fee have all been received by the Office. See Compendium of Copyright Office Practices ("Compendium I") $\$$ 11.1.2.I (1973). This change may have been made to encourage timely submission of application and fee.

${ }^{53}$ See Copyright Act of 1909, $\$ 23$.

${ }^{54}$ See id. $\$ 24$ ("[T] he copyright subsisting in any work at the time when this Act goes into effect may, at the expiration of the term provided for under existing law, be renewed and extended ... for a further period such that the entire term shall be equal to that secured by this Act, including the renewal period...."). 
federal copyright was first secured on July 1,1867 or earlier would expire at or before the end of June 30, 1909, and therefore would not be subsisting on July 1, 1909, and would not be eligible for the increased renewal term.

D. From the joint resolution of September 19, 1962, through the Copyright Act of 1976. On September 19, 1962, Congress passed a joint resolution "[e]xtending the duration of copyright protection in certain cases." ${ }^{25}$ That resolution provided that in any case in which the renewal term of copyright subsisting on September 19, 1962 would expire prior to December 31, 1965, that renewal term would continue until December 31, 1965. ${ }^{56}$ The purpose of that stand-alone extension of term was to keep those works under copyright until Congress could pass a general revision of copyright, which was anticipated to retroactively increase copyright term for all works still under copyright. As the general revision became subject to repeated delay, Congress repeatedly passed additional incremental extensions of term. Over the next 12 years, Congress ended up passing eight additional extensions, thus keeping under copyright through 1976 all works that were still in their renewal term on September 19, 1962. ${ }^{57}$ Finally, in the Copyright Act of 1976, passed on October 19, 1976, Congress provided for a

55 Pub. L. 87-668, 76. Stat. 555 (September 19, 1962). For more detail on interim extension legislation, see Ochoa, supran. 2, at 40-42.

${ }^{56}$ See id. The full text of the resolution provided: "Resolved by the Senate and House of Representatives of the United States of America in Congress assembled, That in any case in which the renewal term of copyright subsisting in any work on the date of approval of this resolution would expire prior to December 31, 1965, such term is hereby continued until December 31, 1965." Id.

${ }^{57}$ See Joint Resolution of August 28, 1965, Pub. L. No. 89-142, 79 Stat. 581 (1965) (extending any renewal term of copyright subsisting on August 28, 1965 to December 31, 1967); Joint Resolution of November 16, 1967, Pub. L. No 90-141, 81 Stat. 464 (1967) (extending any renewal term of any copyright subsisting on November 16, 1967 to December 31, 1968); Joint Resolution of July 23, 1968, Pub. L. No. 90-416, 82 Stat. 397 (1968) (extending the renewal term of any copyright subsisting on July 23, 1968 to December 31, 1969); Joint Resolution of December 16, 1969, Pub. L. no. 91-147, 83 Stat. 360 (1969) (extending the renewal term of any copyright subsisting on Dec. 16, 1969 to December 31, 1970); Joint Resolution of December 17, 1970, Pub. L. No. 91-555, 84 Stat. 1441 (1970) (extending the renewal term of any copyright subsisting on Dec. 17, 1970 to December 31, 1971); Joint Resolution of November 24, 1971, Pub. L. No. 92-170, 85 Stat. 490 (1971) (extending the renewal term of any copyright subsisting on Nov. 24, 1971 to December 31, 1972); Joint Resolution of October 25, 1972, Pub. L. No. 95-566, 86 Stat. 1181 (1972) (extending the renewal term of any copyright subsisting on Oct. 25, 1972 to December 31, 1974); Act of December 31, 1974, Pub. L. No. 93-573, $\$ 104,88$ Stat. 1873 (1974) (extending the renewal term of any copyright subsisting on Dec. 31, 1974 to December 31, 1976). 
renewal term of 47 years, ${ }^{58}$ and a total combined term of 75 years for any work still in its renewal term as of December 31, 1977. ${ }^{59}$ As noted above, the 1976 Act also provided that all terms of copyright would extend to the end of the calendar year during which they would otherwise expire. $^{60}$

The cumulative effect of the incremental extensions of copyright term and of the Copyright Act of 1976 is thus as follows. Any work in which federal copyright had been secured on September 20, 1906 or later, and in which copyright had been validly renewed, was still under copyright on September 19, 1962, 56 years later, and thus ultimately received a total term of 75 years, ending not on the precise date 75 years after the date that copyright was acquired, but at the end of the calendar year in which that date occurred. ${ }^{61}$ Conversely, the term of a work in which federal copyright was first secured on or before September 19, 1906 would expire at or before the end of the day on September 18, 1962, and therefore would not be subsisting on September 19, 1962, and would not be eligible for the 75-year total term.

E. The Sonny Bono Copyright Term Extension Act. Finally, the Sonny Bono Copyright Term Extension Act ("CTEA") was passed on October 27, 1998, ${ }^{62}$ and became effective immediately. ${ }^{63}$ Section 102(d) of that Act provides that the renewal term of copyrights still subsisting on the effective date of the Act would be increased to 67 years, and that any work in which copyright was in its renewal term as of the effective date of the Act would have a term of copyright of 95 years from the date on which copyright was first secured. ${ }^{64}$ Since the 1976 Act provided for end-of-calendar-year expiration of term, any work in which federal copyright had been secured on January 1, 1923 or later, and in which copyright had been validly renewed, would still be under copyright on October 27, 1998. Conversely, the term of copyright of a work in which federal copyright was first secured on or before December 31, 1922 expired no later than the end of the day on December

\footnotetext{
${ }^{58}$ See 17 U.S.C. \$ 304(a) (1976).

${ }^{59}$ See 17 U.S.C. $\$ 304$ (b) (1976).

${ }^{60}$ See 17 U.S.C. $\$ 305(1976)$.

${ }^{61}$ See 17 U.S.C. $\$ \$ 304(a), 304(b), 305$ (1976).

${ }^{62}$ See Sonny Bono Copyright Term Extension Act ("CTEA"), Pub. L. No. 195-298, 112 Stat. 2827. For further background on this Act, see Ochoa, supran. 2, at 40-42.

${ }^{63}$ See id. $\$ 106$.

${ }^{64}$ See id. $\$ 102(d)$.
} 
31, 1997, and therefore was not subsisting on October 27, 1998, and was not eligible for the increased term.

\section{Prospective and Retrospective Copyright Term for Works Acquiring Federal Copyright Protection On or After January 1, 1978.}

The Copyright Act of 1976 prospectively changed both the method of measuring the term of federal copyright protection, and the events that result in acquiring that protection. The basic term of protection for works created on or after January 1, 1978, or created but not published or registered before January 1, 1978, was the life of the work's author plus 50 years. ${ }^{65}$ Works that were created as works made for hire, or that were published anonymously or pseudonymously, received a term equal to the lesser of 75 years after publication or 100 years after creation. ${ }^{66}$ Under the 1976 Act, works receive federal protection upon fixation; neither publication with notice nor registration is necessary, although the original 1976 Act did continue to require copyright notice as a condition of maintaining copyright protection after publication.

Because state common law had generally been thought to provide perpetual protection for unpublished works ${ }^{67}$ and for sound recordings, the Copyright Act of 1976 could be viewed as actually effecting retroactive contractions of copyright term with respect to those works - to date, the only retroactive contractions of term in the history of U.S. copyright law. ${ }^{68}$ However, it would be a mistake to think that the protection afforded under common law copyright was in every respect as extensive and as well-defined as federal protection, so that the 1976 Act's preemption of common law copyright shortened term while maintaining all other aspects of protection. Common law protection, for example, does not offer remedies such as statutory damages or attorney's fees, and the contours of that protection are still being judicially determined: the first opinion to decide that sound

\footnotetext{
${ }^{65}$ See 17 U.S.C. $\$ 302(a)(1976)$.

${ }^{66}$ See 17 U.S.C. $\$ 302(\mathrm{c})(1976)$.

${ }^{67}$ See Wheaton v. Peters, 33 U.S. (8 Pet.) 591 (1834); Melville B. Nimmer \& David Nimmer, Nimmer on Copyright $\$ 9.09$.

${ }^{68}$ See generally R. Anthony Reese, Public but Private: Copyright's New Unpublished Public Domain, 85 Tex. L. Rev. 585 (2007).
} 
recordings enjoyed a public performance right at common law (as it turns out, the common law of New York) was issued in $2014 .{ }^{69}$

Moreover, transition rules softened the effect of the retroactive contractions of term. Regardless of the terms of copyright generally available under the 1976 Act, that Act provided that no unpublished work would enter the public domain until January 1, 2003, 25 years after the effective date of the 1976 Act. Moreover, publication by December 31, 2002 of any work created but not published or registered before 1978 would result in copyright protection through at least December 31, 2027, 50 years after the 1976 Act's effective date. ${ }^{70}$ The CTEA added another 20 years to that minimum term, resulting in protection through at least December 31, 2047. ${ }^{71}$ As for sound recordings fixed before February 15, 1972, which were protected under state rather than federal law, the 1976 Act provided that they would not be governed by federal law, including federal term limitations, until February 15, 2047, 75 years after the last one of them was made. ${ }^{72}$ The CTEA also pushed that date back 20 years, resulting in the preservation of state-law protection until February 15, 2067. ${ }^{73}$

As for works created after December 31, 1977, virtually all of them ended up getting the benefit of another retroactive extension of term. The CTEA extended the basic term of copyright to life of the author plus 70 years, and the term for works made for hire and anonymous and pseudonymous works to the lesser of 95 years after publication or 120 years after creation. ${ }^{74}$ Only a very few works created after December 31, 1977 had fallen into the public domain before the effective date of the CTEA, namely, those that were published without proper copyright notice between January 1, 1978 and February 28, 1989, and for which that deficiency was not cured under available 1976 Act provisions. ${ }^{75}$ All of the rest received the benefit of the CTEA extension.

\footnotetext{
${ }^{69}$ See Flo \& Eddie, Inc. v. Sirius XM Radio, Inc., 113 U.S.P.Q.2d 1285 (S.D.N.Y. 2014).

${ }^{70}$ See 17 U.S.C. $\$ 303$ (1976).

${ }^{71}$ CTEA, supran. 62, \$ $102(\mathrm{c})$.

${ }^{72}$ See 17 U.S.C. $\$ 301($ c)

${ }^{73}$ CTEA, supran. 62, \$ $102(\mathrm{a})$.

${ }^{74} \mathrm{Id}$. $\$ 102(\mathrm{~b})$.

${ }^{75}$ For the general requirement of copyright notice in the original Copyright Act of 1976, see 17 U.S.C. $\$ 401$ (1976). For the means of curing some notice deficiencies, see 17 U.S.C. $\$ 405(a)$ (1976). The Berne Convention Implementation Act, which eliminated the notice requirement, became effective on March 1, 1989. See Berne Convention Implementation Act of 1988, Pub. L. No. 100-568, \& 7 (eliminating the notice
} 


\section{Maximum Copyright Term and Actual Copyright Term}

Although this article has focused principally on maximum copyright term, for most of the history of U.S. copyright law a work could end up receiving far less than the maximum term, and most works did receive far less.

First, from the 1790 Act until the March 1, 1989 effective date of the Berne Convention Implementation Act ${ }^{76}$ publication of a work without the observation of required formalities, which variously over time included registration, copyright notice on copies and/or in newspapers, and deposit, could result in immediate forfeiture of copyright, and injection of the work into the public domain. Second, works that were published before 1978 were all originally granted a split copyright term that required renewal registration to maintain protection after the first portion of that term. Most copyright owners did not take the affirmative steps necessary to renew copyright. ${ }^{77}$ Moreover, for works for which federal copyright was obtained from February 4, 1803 through July l, 1881, renewal was only available to a limited class of persons, which in some circumstances was an empty class, thus foreclosing renewal altogether. ${ }^{78}$ It is therefore possible that the single greatest retroactive extension of actual copyright term, as opposed to maximum copyright term, was effected by the Copyright Renewal Act of 1992. That Act retroactively lifted the requirement of renewal for all works published between January 1, 1964 and December

requirement), $₫ 13$ (defining the Act's effective date), 102 Stat. 2853, 2857-59, 2861 (Oct. 31, 1988).

${ }_{77}^{76}$ Seen. 75 , supra.

${ }^{77}$ For a discussion of historical renewal rates, see William M. Landes $\&$ Richard A. Posner, The Economic Structure of Intellectual Property Law 238-249 (2003).

${ }^{78}$ As noted above, the Copyright Act of 1831 created a new renewal term, which was prospectively for the benefit of the author, if he survived through the end of the initial term, or for his widow and child or children if he did not. The section of the Act that retroactively extended the benefit of the that new renewal term neglected to include the author, and therefore made renewal available only if the author died before the end of the initial term but had a widow and/or a child or children who survived through the end of that term. The Copyright Act of 1909 expanded the class of persons eligible to renew to include executors and heirs, and Section 24 of that Act retroactively applied that expansion to all works still under copyright when the Act became effective. Since the Act became effective on July 1, 1909, that expansion would apply to all works that were still in their initial 28-year term of copyright on that date, which would include all works for which federal copyright was secured on or after July 2, 1881. 
31, 1977. Since far fewer than half of those works would likely have been renewed, the Act retroactively added 47 years of copyright, which under the CTEA ended up becoming 67 years of copyright, to millions of works published during those 13 years. ${ }^{79}$

Thus, just as the history of U.S. copyright law has for the most part been a history of lengthening of maximum copyright term, it has also been for the most part a history of lessening of copyright formalities that could cause actual copyright term to be shorter than maximum term. After the Copyright Renewal Act of 1992, only an a copyright owner's affirmative dedication of a work to the public domain could conceivably result in that work enjoying less than the maximum term of copyright, and it is not completely clear that copyright owners always have the power to make such a dedication. ${ }^{80}$

\section{Conclusion: Looking Back from the Future}

Every time Congress has extended the term of copyright, it has done so retroactively. The Eldred Court charitably suggested that the retroactivity provisions were afterthoughts, motivated by concerns of equal treatment: Congress "grant[ed] to authors of works with existing copyrights the benefit of term extensions so that all under copyright protection will be governed evenhandedly under the same regime." ${ }^{81}$ Under a less charitable interpretation, term extension has always been driven by its retroactive potential - its potential for maintaining the flow of a proven income stream that would otherwise cease immediately. The prospective aspect of term extension concerns an income stream that may or may not exist decades in the future. As Justice Breyer pointed out in dissent in Eldred, under conservative assumptions about discount rates, the prospective extension of term from life plus 50 to life plus 70 increases the present value of a work

\footnotetext{
${ }^{79}$ A competitor for the title of greatest retroactive extension of copyright term might be the Uruguay Round Agreements Act, Pub. L. No 103-465, \$ 514 (December 8, 1994), 108 Stat. 4809, 4976, which restored copyright in a large number of foreign works that had fallen into the public domain in the United States due to publication without proper copyright notice or failure to file an application to renew.

${ }^{80}$ See, e.g., Lydia Pallas Loren, Building a Reliable Semicommons of Creative Works: Enforcement of Creative Commons Licenses and Limited Abandonment of Copyright, 14 Geo. Mason L. Rev. 271, 314-326 (2007); Timothy K. Armstrong, Shrinking the Commons: Termination of Copyright Licenses and transfers for the Benefit of the Public, 47 Harv. J. on Legis. 359, 388-399 (2010)

${ }^{81}$ Eldred, 537 U.S. at 200.
} 
when created by only one-third of one percent; even that assumes that the income stream from the work remains constant, as it does in only a very small percentage of cases. ${ }^{82}$ And as I have noted elsewhere, even though publishers argued that U.S. copyright term should be extended so that U.S. works would gain protection for life plus 70 in Europe, they generally seem to be simultaneously publishing U.S. works in Canada, which under Berne Convention rules will in many cases limit European protection for those works to life plus $50 .^{83}$ That in turn suggests that those publishers are not very interested in prospective term extension. If it is the prospect of retroactive extension that has motivated the increase in copyright term, then it may be the prospective extension that is the afterthought, motivated less by equality than by avoiding the perception of naked greed.

Will the retrospective maximum term of copyright ever again equal the prospectively announced term? The first works created with the expectation that they would receive a term of life of the author plus 70 years were created on October 27, 1998. Those works will not fall into the public domain until at least January 1, 2069, and that will be the case only for a small percentage of those works, namely, those whose authors died by December 31, 1998. Nonetheless, if Congress does not in the meantime again retroactively extend copyright term, some group may prepare to toast at midnight on New Year's Eve, 2068, the return of coincidence between prospective and retrospective maximum copyright term. Whoever proposes the toast on that occasion may note that the last time that works began entering the public domain after a term that was announced at the time they gained federal copyright protection was midnight on February 2, 1873, when works for which copyright was acquired under the 1831 Act and properly renewed began to fall into the public domain. ${ }^{84}$ By any mortal measure, that is a long interlude.

${ }^{82}$ See Eldred, 537 U.S. at 267-68 (Breyer, J., dissenting).

${ }^{83}$ See Robert Brauneis, Do most US authors still only enjoy a copyright term of life plus 50 in the EU?, Kluwer Copyright Blog (Jan. 27, 2014), available at http://kluwercopyrightblog.com/2014/01/27/do-most-us-authors-still-only-enjoy-acopyright-term-of-life-plus-50-in-the-eu/ (last visited May 22, 2015).

${ }^{84}$ Works that acquired federal copyright protection beginning on February 3, 1831, the date of passage of the 1831 Act, and enjoyed the maximum term of copyright of 42 years, began entering the public domain on February 3, 1873. Works that acquired federal copyright protection for 36 years following February 3, 1831 ended up getting the same 42 years maximum protection that had been announced at the time of gaining that protection. That lasted through July l, 1867, because a work that gained 